\title{
Jesus and John Wayne: How White Evangelicals Corrupted a Faith and Fractured a Nation
}

\author{
By Kristin Kobes Du Mez
}

Reviewed by Christine Albertini

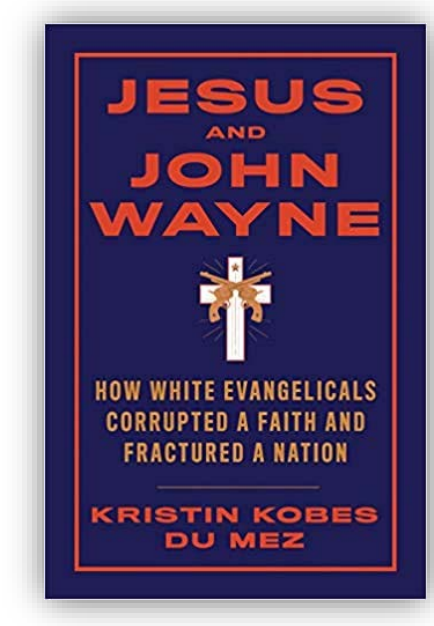

New York: Liveright (Norton) 2020

For anyone seeking to understand the currents pummeling our national life, Jesus andJohn Wayne is a must-read. In fact, it's a page-turner. Its insightful window into Christian evangelicalism shows this movement as a riptide in the U.S. cultural sea change of the past half-century. With meticulous research and abundant footnoting, Kristen Kobes Du Mez unpacks such a straightforward narrative that it quickly begins to seem obvious.

One can look to the book's subtitle (How White Evangelicals Corrupted a Faith and Fractured a Nation) to know the author's point of view. In Chapter One, she makes the case that evangelicalism has drifted so far from the Jesus of the Gospels that it must be considered more a cultural movement than a religious one. It does not follow the Jesus of the Sermon on the Mount, but rather Jesus, "a spiritual bad-ass", to quote a popular evangelical figure (247). This Jesus recruits defenders of the movement's foundational belief in biblically mandated male authority and women's subordination. Convinced that this mandate is under continuous assault, the cause has enshrined an increasingly militaristic, racist, militant Christian masculinity.

Subsequent chapters reach back through the twentieth century to explain how we got here. Beginning with Teddy Roosevelt (the original bombastic, cowboy president), each era has produced the movement's heroes (from John Wayne to George W. Bush), foot soldiers (including Jerry Falwell, and a parade of televangelists) and villains (Bill Clinton, Barak Obama, and most especially, Hillary Clinton). The book documents a robust, coordinated network of political, church, publishing, and para-church organizations. What is revealed is a group so aggrieved and threatened that it waged a battle to take-over the U.S. military, political life, courts, and public schools, with a remarkable degree of success. Its zenith in the election of Donald Trump can be understood in this way: "Evangelicals hadn't betrayed their values. Donald Trump was the culmination of their half-century-long pursuit of a militant Christian masculinity" (271).

I attended a recent online book-talk with the author. She comes to this subject with the authority of a scholar and a close observer. She grew up and was educated in a rural, evangelical environment in Iowa. She is professor of history at Calvin University in Grand Rapids, MI, a school of the Christian Reformed faith, considered an evangelical denomination. She is careful to state that her views are her own. She expressed being drawn to this topic because of the roots she shares with a movement whose current manifestation she doesn't recognize (2). She thought, "Who better to hold these views up to the light, to examine and deconstruct them?" One only need follow her Twitter account (@kkdumez) to see that she has 'stirred the pot'.

So, if you're scratching your head about our national division over Confederate monuments, Black Lives Matter, the Supreme Court, public schools, or who won the 2020 presidential election, you will want to read this book. Whether you see yourself in this story or see it as a chilling morality tale, allow Professor du Mez to illuminate the darkness in which we walk. 


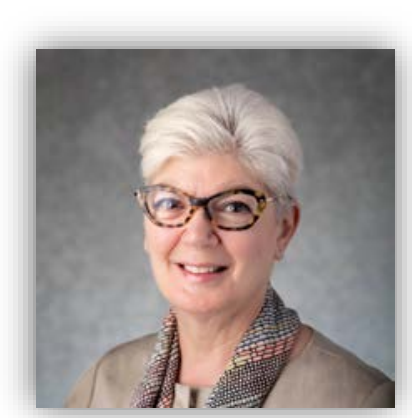

Christine Albertini is a student in the MA in Theological and Cultural Anthropology program at Eastern University. She works at the intersection of business and education to ensure that all people have access to the economic benefits of society. Her research interest examines how gender norms in different religions effect women's access to the economic life of their community, and explores ways to measure the spiritual impact afforded by underlying economic stability.

Author email: christine.albertini@eastern.edu 